\title{
Natriuretic hormone: the ultimate determinant of the preservation of external sodium balance
}

\section{Neal S. Bricker ${ }^{1}{ }^{*}$, Christopher D. Cain ${ }^{2}$ and Stewart Shankel ${ }^{3}$}

1 School of Medicine, University of California at Los Angeles, Los Angeles, CA, USA

2 Phytoanalytics, Grand Terrace, CA, USA

${ }^{3}$ Department of Medicine, School of Medicine, University of California at Riverside, Riverside, CA, USA

Edited by:

Harvey Craig Gonick, University of California, Berkeley, USA

\section{Reviewed by:}

Joao Carlos Dos Reis Cardoso,

University of Algarve, Portugal

Vardaman Buckalew, Wake Forest

School of Medicine, USA

*Correspondence:

Neal S. Bricker, 727 South Orange

Grove Blvd., Suite 6, Pasadena, CA

91105, USA

e-mail: nealbricker@ca.rr.com
The present manuscript focuses on a putative natriuretic hormone. It includes the history of a long-term search for the pure molecule, ranging from partial purification to synthesis. It includes a description of seven different bioassay systems used, a resume of the sequential steps in purification, and a summary of a series of experimental protocols employed in the effort to define the biologic properties of the inhibitor of sodium $(\mathrm{Na})$ transport. Two closely related molecules were purified and synthesized. Both are xanthurenic acid derivatives (xanthurenic acid 8-O- $\beta$-D-glucoside and xanthurenic acid 8-O-sulfate). It is concluded that one or both of these two low molecular weight compounds (MW: 368 and 284) meet many of the criteria for the final modulator of $\mathrm{Na}$ excretion.

Keywords: natriuretic hormone, sodium transport, ENaC, xanthurenic acid derivatives, synthesized NH

\section{INTRODUCTION}

It is our assumption that there is a single natriuretic hormone that serves to modulate the renal excretion of sodium $(\mathrm{Na})$ so as to preserve an ongoing equality between consecutive $24 \mathrm{~h} \mathrm{Na}$ excretion by the kidneys and the contemporaneous intake of $\mathrm{Na}$. The focus on what we presume to be a hormone was initiated from the classic experiments of DeWardener et al. (1-3). The present symposium provides a contemporary review of the state-of-theart of natriuretic hormone research by key investigators who have pursued the identity and biologic properties of several different putative natriuretic hormones.

Because of the design of DeWardener's protocol, it appeared likely that all of the factors then known to affect the renal excretion of $\mathrm{Na}$ could be excluded as the definitive control element. These included changes in glomerular filtration rate (GFR) (socalled "first factor") and changes in mineralocorticoid hormone activity ("second factor"). We coined the term "third factor" (4), which subsequently was replaced by "natriuretic factor."

Throughout a long period of time, a multinational group of investigators has sought to isolate and characterize the natriuretic hormone. To this point in time, despite considerable progress, the ultimate goal remains elusive. Hence, the present symposium.

Our interest in an endogenous natriuretic hormone arose out of long-term studies on the pathologic physiology of chronic progressive renal disease (CRD) (5). It was the pattern of $\mathrm{Na}$ excretion that evolved as nephron destruction proceeded.

What is a remarkable change in the estimated $\mathrm{Na}$ excretion rate per nephron from the beginning to the end of CRD is presented in Table 1. In constructing this table, the intake of Na per $24 \mathrm{~h}$ was maintained constant (e.g., at $120 \mathrm{mEq} /$ day) and at all levels of GFR, external Na balance was preserved (the latter is not unusual down to a GFR as low as $10 \%$ of normal.).

At a normal GFR of $120 \mathrm{ml} / \mathrm{min}$ in an $80 \mathrm{~kg}$ person, Na balance is achieved by the excretion of $1 / 2$ of $1 \%$ of the filtered load of
Na. A fall in GFR to $60 \mathrm{ml} / \mathrm{min}$ mandates the excretion of $1 \%$ of the filtered $\mathrm{Na}$. A further reduction of GFR (to $30 \mathrm{ml} / \mathrm{min}$ ) due to the progression of the underlying renal disease requires the excretion of $2 \%$ of the filtered $\mathrm{Na}$. And at a GFR of $15 \mathrm{ml} / \mathrm{min}$, external $\mathrm{Na}$ balance is achieved by the excretion of $4 \%$ of the filtered $\mathrm{Na}$. Thus, per unit of $\mathrm{Na}$ entering the extracellular fluid on a constant Na intake, the excretion rate per milliliter of residual GFR with no time delay increases by eightfold. Finally, in many forms of CRD, single nephron GFR (SNGFR) doubles as nephron loss advances. Na excretion rate per residual nephron per milliequivalents of $\mathrm{Na}$ intake, approaches 16 times the value in the normal subject.

\section{BIOASSAY SYSTEMS}

Seven different bioassay systems were used in both the sequential steps in the isolation, purification, and synthesis of $\mathrm{NH}$ and the studies of the biologic effects of the test materials. Each assay system allowed for a quantitative measure of the inhibitory effects of a test sample on $\mathrm{Na}$ transport either in vitro or in vivo.

The primary in vitro systems (frog skin and toad bladder) (6, 7) involve polar epithelial cells that transport $\mathrm{Na}$ from the serosal surface of the membrane across the mucosal surface. Na transport is quantified by the short-circuit current across the isolated membrane (in an Ussing chamber). Activity of partially purified to pure $\mathrm{NH}$ was detectable only when the inhibitor was added to the serosal surface of the membrane.

In micropuncture studies (8), isolated cortical collecting tubules, dissected from normal rabbits were perfused with partially purified test material from the urine of uremic patients. The perfusate was delivered into the lumen of each nephron segment and the peritubular surface was bathed in a solution of known composition (see Experimental Data).

The in vivo assays were performed in rats (9). The test materials were delivered intravenously, intraarterially, or via a gastric tube. 
Table 1 | Adaptation in $\mathrm{Na}$ excretion per nephron in advancing CRD on a constant salt intake.

\begin{tabular}{llllll}
\hline $\begin{array}{l}\text { GFR } \\
\mathbf{m l} /\end{array}$ & $\begin{array}{l}\text { Na in } \\
\mathbf{m E q} / \\
\mathbf{m n}\end{array}$ & $\begin{array}{l}\text { Na out } \\
\mathbf{m E q} /\end{array}$ & $\begin{array}{l}\boldsymbol{\mu} \text { I SNGFR } \\
\text { day of } \\
\text { normal }\end{array}$ & $\begin{array}{l}\text { Na out } \\
\text { per nephron } \\
\mathbf{n E q}\end{array}$ & $\begin{array}{l}\text { Magnification } \\
\text { per nephron }\end{array}$ \\
\hline 120 & 120 & 120 & 100 & 700 & 1 \\
60 & 120 & 120 & & 1,400 & 2 \\
30 & 120 & 120 & & 2,800 & 4 \\
15 & 120 & 120 & 200 & 5,600 & 8 \\
$71 / 2$ & 120 & 120 & & 11,212 & 16 \\
\hline
\end{tabular}

See text in reference to the increase in SNGFR. Column 6 depicts the exponential increase in sodium excretion per nephron per unit of sodium intake.

In the rat assay, the rats employed had: (1) two normal kidneys; (2) one remnant kidney (75\% reduction of renal mass) and a contralateral normal kidney; or (3) a solitary remnant kidney following removal of the normal kidney.

\section{PURIFICATION OF NH}

Twenty-four hour collections of urine were reduced from their original volume to approximately $20 \mathrm{ml}$ of sludge by lyophilization. The sludge was then redissolved in isotonic saline to $25 \mathrm{ml}$ components each equal to $6 \mathrm{~h}$ of original urine. Each sample then was chromatographed through Sephadex G-25 with online monitoring of UV absorption at $290 \mathrm{~nm}$ and electrical conductivity (10).

Biologic activity was limited to the "post-salt" peaks using the frog skin assay (11). Short-circuit current decreased from 40-50 to 20-30 $\mu \mathrm{Amp} / \mathrm{cm}^{2}$. These samples were purified using high performance liquid chromatography (HPLC) runs. The active fractions were purified further by two consecutive HPLC runs. The eluate was monitored by fluorescence and UV absorbance.

After further concentration, a bioassay was performed by infusion of the test material into the uremic rat (11). A strong and sustained natriuresis was recorded.

The natriuretic fractions, consistently showed two peaks with strong fluorescence (excitation $332 \mathrm{~nm}$; emission $430 \mathrm{~nm}$ ) and characteristic UV absorption (UV max at $338 \mathrm{~nm}$ ). These spectroscopic signatures were used as the main pooling criteria for further HPLC-based purification of $\mathrm{NH}$ (11). Additional steps in isolation, purification, and synthesis of the two molecules: xanthurenic acid 8 -O- $\beta$-D-glucoside and xanthurenic acid 8-O-sulfate are described in a separate publication (11).

\section{EXPERIMENTAL DATA}

\section{UREMIC VS. CONTROL SUBJECTS}

Based on the adaptation in Na excretion in advancing CRD (see Table 1), bioassays were performed on normal rats using partially purified urine samples from 17 patients with advanced CRD (mean GFR $8.7 \mathrm{ml} / \mathrm{min}$ ) and 14 normal control subjects. The assays from the normal subjects were negative [i.e., no significant increase in either absolute $\mathrm{Na}$ excretion $\left(\mathrm{U}_{\mathrm{Na}} \mathrm{V}\right)$, or the fraction of filtered $\mathrm{Na}$ excreted $\left(\mathrm{FE}_{\mathrm{Na}}\right)$ (12)]. The uremic fractions produced a highly significant increase from baseline levels in both parameters of $\mathrm{Na}$ excretion. With more concentrated samples of the uremic urine fractions, values for $\Delta \mathrm{FE}_{\mathrm{Na}}$ rose to levels as high as $12 \%$.

\section{ADVANCED CRD WITH A SUPERIMPOSED EDEMA-FORMING STATE: (THE NEPHROTIC SYNDROME)}

Eight patients with advanced CRD and the nephrotic syndrome were studied (12). Assays were performed on normal rats using partially purified fractions of serum in all eight studies. Fractions of urine were also used in three studies. Values for $\mathrm{U}_{\mathrm{Na}} \mathrm{V}$ decreased from control levels (by an average of $0.97 \mu \mathrm{Eq} / \mathrm{min}$ ). The mean value for $\mathrm{FE}_{\mathrm{Na}}$ also decreased (1.35\%).

Danovitch et al. (13) studied a group of five patients with far advanced CRD (GFR 5.2-16.0 $\mathrm{ml} / \mathrm{min}$ ) who initially were in $\mathrm{Na}$ balance on controlled metabolic diets containing from 58 to $342 \mathrm{mEq}$ of $\mathrm{Na}$ per day. In each patient, while under close observation (clinical and laboratory), the $\mathrm{Na}$ content of the diet was reduced at intervals of 1 week or longer over 4-14 weeks. Four of the patients exhibited a salt-losing state, wherein $\mathrm{Na}$ excretion exceeded $\mathrm{Na}$ intake. Two of these patients required intravenous salt replacement. At the completion of the studies, all patients maintained external $\mathrm{Na}$ balance while ingesting a mean of $5.0 \pm 2.9 \mathrm{mEq}$ of $\mathrm{Na}$ /day. Thus, in contrast to patients with advancing CRD who maintain Na balance on a constant salt intake and a progressively decreasing nephron population, these patients were subjected to a progressive reduction of $\mathrm{Na}$ intake with an unchanging nephron population. (GFR remained constant throughout the studies.) The adaptive increase in $\mathrm{Na}$ excretion in advancing CRD (Table 1), thus was reversed with slow (and cautious) serial reductions in salt intake. The salt-losing tendency of CRD was reversed.

\section{MICROPUNCTURE STUDIES}

As described under Bioassay Systems, partially purified natriuretic factor was infused into the lumen of isolated cortical collecting tubules of normal rabbits. No effect was observed with intraluminal infusions. However, when the natriuretic material was added to the solution bathing the peritubular surface, the effects were rapid in onset and highly significant. Net Na flux (measured isotopically) from luminar to peritubular surface of the nephrons, decreased from 6.29 to $3.20 \mathrm{pmol} / \mathrm{s}(p<0.001)$ with no change in $\mathrm{Na}$ flux in the opposite direction. Potential difference rose rapidly from -22.5 to $-12 \mathrm{mV}$. Control studies, using the same fraction from normal subjects, had no effect (8).

\section{STUDIES ON NORMAL HUMAN BEINGS EXPOSED TO WATER IMMERSION}

Epstein et al. (14) have established water immersion to the neck as a reliable and reproducible stimulus evoking natriuresis in normal subjects. The experiments were performed on 12 normal adults (15). Each was studied twice - once under control conditions sitting in a chair and again during water immersion. The paired studies were performed at the same time of day. Partially purified urine samples were assayed for natriuretic activity in normal rats.

$\mathrm{U}_{\mathrm{Na}} \mathrm{V}$ and $\mathrm{FE}_{\mathrm{Na}}$ did not change from the baseline values in the control studies. During water immersion $\mathrm{U}_{\mathrm{Na}} \mathrm{V}$ rose $(1.27 \pm 0.28 \mu \mathrm{Eq} / \mathrm{min})$ and $\mathrm{FE}_{\mathrm{Na}}$ increased from pre-immersion baseline values by $1.29 \pm 0.21 \%$. Both changes were highly significant $(p<0.001)(15)$. 


\section{STUDIES IN DOGS}

Normal dogs were maintained on a $\mathrm{Na}$ intake varying from 3 to $258 \mathrm{mEq} /$ day, with and without fludrocortisone. Urine was partially purified and assayed for natriuretic effect in normal rats and for inhibition of $\mathrm{Na}$ transport in isolated toad bladders. In dogs on the $258 \mathrm{mEq} \mathrm{Na}$ diet and $0.2 \mathrm{mg}$ fludrocortisone/day, both a statistically significant natriuretic response and inhibition of short-circuit current $(p<0.001)$ were observed. In dogs fed $3 \mathrm{mEq}$ of $\mathrm{Na}$ per day with fludrocortisone, no significant effect was found in either assay system (16).

\section{END-ORGAN RESPONSIVENESS}

The effects of nephron loss on the natriuretic response (9) to partially purified natriuretic factor were studied in three groups of rats, each on a normal salt diet.

1. Group 1: normal rats: intraarterial infusion into one renal artery produced a unilateral natriuresis.

2. Group 2: intraarterial infusion into the renal artery of a unilateral remnant kidney in rats with a contralateral normal kidney produced an increase in $\mathrm{FE}_{\mathrm{Na}}$, which was equal bilaterally. Intravenous infusion of the natriuretic fraction also produced comparable increments of $\mathrm{FE}_{\mathrm{Na}}$ in the remnant and the normal kidneys.

3. Group 3: in uremic rats with a solitary remnant kidney (no contralateral kidney), the intraarterial infusion of natriuretic factor produced an increase in $\mathrm{FE}_{\mathrm{Na}}$ that was significantly greater than in remnant kidneys of group 2 rats or normal kidneys of group 1 .

\section{NATRIURETIC RESPONSE TO SYNTHESIZED (PURE) NH}

Synthesized preparations of xanthurenic acid $8-\mathrm{O}-\beta$-D-glucoside $(\mathrm{NH})$ and xanthurenic acid $8-\mathrm{O}$-sulfate $(\mathrm{NH}-1)$ were bioassayed in normal rats (11).

The intravenous infusion of $\mathrm{NH}$ (range $0.14-16.4 \mathrm{nmol}$ ) and NH-1 (0.7-4.21 nmol) was studied in eight and five normal rats, respectively. In the $\mathrm{NH}$ group, $\Delta \mathrm{U}_{\mathrm{Na}} \mathrm{V}$ averaged $3.68 \pm 0.55 \mu \mathrm{Eq} / \mathrm{min}$; in the five experiments in which $\mathrm{NH}-1$ was the test substance, $\Delta \mathrm{U}_{\mathrm{Na}} \mathrm{V}$ averaged $4.33 \pm 0.71 \mu \mathrm{Eq} / \mathrm{min}$ (1).

In five additional studies, a combination of $\mathrm{NH}(1.4-3.41 \mathrm{nmol})$ and $\mathrm{NH}-1$ (1.75-5.44 nmol) was assayed. $\Delta \mathrm{U}_{\mathrm{Na}} \mathrm{V}$ averaged $5.0 \pm 0.89 \mu \mathrm{Eq} / \mathrm{min}$.

\section{STUDIES BY HOFFMAN AND ASSOCIATES}

In a recent publication, Hoffman et al. (17) studied the effects of xanthurenic acid 8-O- $\beta$-D-glucoside on $\mathrm{Na}$ excretion in adult male Sprague-Dawley rats. Each rat was given two consecutive incremental doses $(6.3+31.5 \mathrm{nmol})$ of $\mathrm{NH}$ (designated as XAG). Values for $\Delta \mathrm{U}_{\mathrm{Na}} \mathrm{V}$ were $3.21 \pm 1.12$ and $3.99 \pm 0.95$ at the two dosages, respectively. Values for $\Delta \mathrm{FE}_{\mathrm{Na}}$ increased significantly $(1.63 \pm 0.46)$ during the second dose of XAG.

In these studies, GFR (inulin clearance) remained unchanged. Mean arterial pressure (MAP) and total renal blood flow were recorded electronically every $5 \mathrm{~min}$ for $60 \mathrm{~s}$ during the control periods and for 30-40 min periods during the XAG infusions. All hemodynamic values remained stable (17).

Two important new observations were made by Hoffman and coworkers:
1. In rats pretreated with amiloride, an inhibitor of $\mathrm{E}_{\mathrm{Na}} \mathrm{C}$, the epithelial $\mathrm{Na}$ channel in the distal tubule, the natriuretic effects of XAG were completely abolished (17).

2. In rats subjected to chronic blockade of the NO system, the natriuretic response to XAG was diminished suggesting to these investigators that the renal effects of XAG could be mediated in part by activation of the renal NO system (17).

\section{DISCUSSION}

A large number of factors, both humoral and physical are known to influence the renal tubular transport of Na. But none of these, including changes in GFR or mineralocorticoid hormone activity (see Introduction) is believed to be the final modulator of net $\mathrm{Na}$ transport and thus of $\mathrm{Na}$ excretion. We believe that natriuretic hormone fulfills this role. It thus would serve as the definitive element of a sophisticated biologic control system that is charged with the preservation of $\mathrm{Na}$ balance and with the constancy of the extracellular fluid volume. But, while there may be virtual unanimity of opinion about the existence of natriuretic hormone, there is no such unanimity about the nature of this hormone.

In this manuscript, we have reviewed the properties of a natriuretic factor, which we have pursued for a long period of time. The activity was obtained from both serum (or plasma) and urine using material that ranged from partially purified to pure, chemically synthesized molecules (11). We believe that the experimental data reviewed in the manuscript meet at least some of the criteria for natriuretic hormone. These include:

1. The rapid and reversible inhibition of net Na transport across polar epithelial cell systems, including the distal portion of the nephron.

2. The foregoing biologic activity is present only when the inhibitor is added to the peritubular surface of the nephron or the serosal surface of equivalent in vitro models.

3. The natriuretic effect of the purified and synthesized material is completely blocked by prior administration of amiloride, an inhibitor of $\mathrm{E}_{\mathrm{Na}} \mathrm{C}$ activity in the distal portion of the nephron.

The mechanism of this action could relate either to a direct effect on the number and/or the activity of $\mathrm{E}_{\mathrm{Na}} \mathrm{C}$ channels, or to a change in the relation between open vs. closed $\mathrm{E}_{\mathrm{Na}} \mathrm{C}$ channels.

4. Inhibition of $\mathrm{Na}$ transport in the distal nephron associated with a rapid shift in transepithelial electric potential difference (i.e., a less negative intraluminal potential).

This change would favor the excretion of $\mathrm{Cl}$ with $\mathrm{Na}$ as opposed to increased secretion of $\mathrm{K}$.

5. No evidence for a fixed coupling ratio between the inhibition of Na transport and $\mathrm{K}$ secretion.

6. Increase in natriuretic activity in advancing CRD in purified serum or urine samples.

7. An increase in end-organ responsivity to the inhibitor associated with nephron loss.

8. Lack of natriuretic effect of the inhibitor in patients with advanced CRD and a superimposed edema-forming state (the nephrotic syndrome).

9. Reversal of salt-losing state in advanced CRD by progressive slow reduction of salt intake to very low levels. 
Table 2 | A comparison of several natriuretic substances.

\begin{tabular}{|c|c|c|c|c|c|c|c|}
\hline & \multirow[t]{2}{*}{ Ouabain (OLS) } & \multirow{2}{*}{$\begin{array}{l}\text { Marinobufogenin } \\
\text { (MFG) }\end{array}$} & \multirow{2}{*}{$\begin{array}{l}\text { Vanadium } \\
\text { diascorbate } \\
\text { (VD) }\end{array}$} & \multicolumn{3}{|c|}{ Atrial natriuretic peptides } & \multirow{2}{*}{$\begin{array}{l}\text { Xanthurenic acid } \\
\text { 8-O- } \beta \text {-D-glucoside } \\
\text { (XAG) }\end{array}$} \\
\hline & & & & ANP & BNP & CNP & \\
\hline Isolation & $\begin{array}{l}\text { Plasma and } \\
\text { adrenal cortex } \\
\text { and } \\
\text { hypothalamus } \\
\text { (18-23) }\end{array}$ & $\begin{array}{l}\text { Plasma, urine, } \\
\text { and adrenal } \\
\text { cortex }(24,25)\end{array}$ & $\begin{array}{l}\text { Urine and plasma } \\
\text { (26) }\end{array}$ & $\begin{array}{l}\text { Atria, heart, and } \\
\text { kidney (27) }\end{array}$ & $\begin{array}{l}\text { Brain, } \\
\text { heart, and } \\
\text { kidney (27) }\end{array}$ & $\begin{array}{l}\text { Brain, heart, } \\
\text { and } \\
\text { vasculature } \\
(27,28)\end{array}$ & $\begin{array}{l}\text { Plasma and urine } \\
\text { from uremic patients } \\
(6,8,10,29)\end{array}$ \\
\hline Stimulus & $\begin{array}{l}\text { All, ACTH, } \uparrow \text { BP } \\
\text { positive sodium } \\
\text { balance or intake; } \\
\uparrow \text { serum } \mathrm{K}+\text { up to } \\
5 \mathrm{mEq} / \mathrm{l}\end{array}$ & Same as OLS & $\begin{array}{l}\text { Salt loading, } \\
\text { aldosteronism, } \\
\text { and volume } \\
\text { expansion (26) }\end{array}$ & $\begin{array}{l}\text { Stretch of cardiac } \\
\text { wall - especially } \\
\text { the atria, ET } \\
\text { adrenergic stimuli } \\
\text { (30) }\end{array}$ & $\begin{array}{l}\text { Same as } \\
\text { ANP (30) }\end{array}$ & $\begin{array}{l}\text { Same? as } \\
\text { ANP (30) }\end{array}$ & $\begin{array}{l}\text { Normal and uremic } \\
\text { patients and animals } \\
(10,15)\end{array}$ \\
\hline M.W. & $584.6(31)$ & $387 ? 600 ?$ (31) & 403 & $\begin{array}{l}2,000-3,000 \pm \\
(32)\end{array}$ & $\begin{array}{l}2,000- \\
3,000 \pm \\
(32)\end{array}$ & $\begin{array}{l}2,000- \\
3,000 \pm \\
(32)\end{array}$ & $\begin{array}{l}368 \text { (glucoside) } 284 \\
\text { (sulfate) (11) }\end{array}$ \\
\hline Structure & Steroid (31) & Steroid (31) & $\begin{array}{l}\text { Vanadate } \\
\text { diascorbate from } \\
\text { ascorbic acid (26) }\end{array}$ & 28 AA (32) & 32 AA (32) & 22 AA (32) & $\begin{array}{l}\text { 8-O-(-D-glucoside } \\
\text { 8-O-sulfate of } \\
\text { xanthurenic acid } \\
\text { from tryptophan (11) }\end{array}$ \\
\hline Site of Action & $\begin{array}{l}\alpha 2 \alpha 3 \text { NaK ATPase } \\
\text { primarily (18-23, } \\
25,26,33-43) \\
\text { acts on } \\
\text { basolateral } \\
\text { membrane of } \\
\text { PCT and NHE3 in } \\
\text { PCT }(36,37)\end{array}$ & $\begin{array}{l}\text { a1 NaK ATPase in } \\
\operatorname{PCT}(24,44)\end{array}$ & $\begin{array}{l}\text { NaK ATPase in } \\
\text { PCT acts on } \\
\text { basolateral } \\
\text { membrane(26) }\end{array}$ & $\begin{array}{l}\text { Blocks ENaC, } \uparrow \\
\text { GFR, blocks NaK } \\
\text { ATPase All in PCT } \\
(30,45,46) \downarrow \\
\mathrm{H}_{2} \mathrm{O} \text { absorption in } \\
\mathrm{CT}, \downarrow \text { urine } \\
\text { concentration (47, } \\
48)\end{array}$ & $\begin{array}{l}\text { Similar to } \\
\text { ANP }\end{array}$ & $\begin{array}{l}\text { Direct } \\
\text { vasodilator } \\
\text { and simulator } \\
\text { to ANP (47) }\end{array}$ & $\begin{array}{l}\text { Blocks } \mathrm{ENaC} \text { acts } \\
\text { from basolateral } \\
\text { surface (17) }\end{array}$ \\
\hline Natriuresis & $\begin{array}{l}\text { Variable from no } \\
\text { natriuresis to mild } \\
\text { natriuresis }(21, \\
25,33,36,38, \\
\text { 39)No effect on } \\
\text { a1-NaK ATPase }\end{array}$ & $\begin{array}{l}\text { Variable } \\
\text { natriuresis (24, } \\
\text { 44) }\end{array}$ & $\begin{array}{l}\text { Moderate } \\
\text { natriuresis (26) }\end{array}$ & $\begin{array}{l}\text { Moderate } \\
\text { through CGMP } \\
(28,30,32,46)\end{array}$ & $\begin{array}{l}\text { Same as } \\
\operatorname{ANP}(28,30, \\
32,46,49)\end{array}$ & None $(28,47)$ & $\begin{array}{l}\text { Eliminated by } \\
\text { blocking ENaC (17) }\end{array}$ \\
\hline $\mathrm{RBF}$ & $\downarrow(40)$ & $?$ & $?$ & $\begin{array}{l}\uparrow \mathrm{RBF} \rightarrow \uparrow \mathrm{GFR} \\
(30,45,50)\end{array}$ & Variable (50) & No & No effect (17) \\
\hline GFR & $\begin{array}{l}\downarrow \text { Or no change } \\
(40)\end{array}$ & $?$ & $?$ & $\begin{array}{l}\uparrow \text { GFR dilates } \\
\text { afferent arteriole } \\
\text { and constricts } \\
\text { efferent (49) }\end{array}$ & $\begin{array}{l}\text { Same as } \\
\text { ANP (49) }\end{array}$ & No & No effect (17) \\
\hline K excretion & $\downarrow$ & $\downarrow$ & $\downarrow$ & $\uparrow$ & $\uparrow$ & $\uparrow$ & Minimal (11) \\
\hline Vasoactivity & $\begin{array}{l}\uparrow \mathrm{BP}, \\
\text { vasoconstriction } \\
(21,22,33,34, \\
36,40-43) \uparrow \mathrm{Ca} \\
\text { influx and } \mathrm{Na} \\
\text { influx into vessel } \\
\text { wall (22, 34, } \\
42-44)\end{array}$ & $\begin{array}{l}\uparrow \mathrm{BP}, \\
\text { vasoconstriction } \\
(24,44)\end{array}$ & $\begin{array}{l}\uparrow \mathrm{BP}(27) \uparrow \mathrm{Ca} \\
\text { and } \mathrm{Na} \text { influx into } \\
\text { vessel wall (25, } \\
27 \text { ) }\end{array}$ & $\downarrow \mathrm{BP}(32,47)$ & $\begin{array}{l}\downarrow \mathrm{BP}(32, \\
47)\end{array}$ & $?$ & None (17) \\
\hline
\end{tabular}


10. Presence of natriuretic activity in urine of normal subjects during water immersion - an experience known to produce central hypervolemia.

11. Increased natriuretic activity in normal dogs on a high salt diet and superimposed mineralocorticoid hormone.

12. No natriuretic activity in normal dogs on a low salt diet and superimposed mineralocorticoid hormone.

\section{OTHER "NATRIURETIC" FACTORS}

Four other categories of putative natriuretic hormones are considered in separate papers in this symposium. These compounds include: (1) ouabain [or ouabain-like substances (OLS)]; (2) marinobufogenin (MFG); (3) vanadium diascorbate (VD); and atrial natriuretic peptides (ANP).

A summary of key properties of each is shown in Table 2 and a brief description of some relevant characteristics follows.

\section{OUABAIN (OLS)}

A small molecule (MW 584.6) isolated from plasma (18), urine, adrenal cortex, and hypothalamus (19-23). The primary and relevant effects are the inhibition of NaK ATPase and the cross reaction with ouabain antibodies (21).

But they are inconsistently natriuretic $(21,22,33,34)$, presumably because ouabain has little effect on the $\alpha 1$ subunit of $\mathrm{NaK}$ ATPase $(22,35)$. Indeed, there also recent evidence that OLS may actually cause $\mathrm{Na}$ retention (26).

\section{MARINOBUFOGENIN}

Also a small molecule (MW between 387 and 600) (31), which is isolated from plasma, urine, and the adrenal cortex $(24,44)$. No studies have shown that administration of MFG causes natriuresis in assay animals. However, administration of anti-MBG antibodies reduces $\mathrm{Na}$ excretion $(24,44)$. Exogenous administration of bufalin, a very closely related compound, injected into the renal artery of sheep has been shown to produce natriuresis. No similar studies have as yet been published using MFG (51).

\section{VANADIUM DIASCORBATE}

A small molecule (MW 403) isolated from plasma and urine (26). Inhibits NaK ATPase in the proximal convoluted tubule. Produces moderate natriuresis, may produce influx of $\mathrm{Ca}^{++}$into vessel walls and thereby increase BP.

\section{ATRIAL NATRIURETIC PEPTIDES}

Molecular weight 2,000-3,000 \pm (32). The natriuretic peptides, while producing natriuresis, also increase GFR and increase glomerular pressure by dilating the afferent arteriole, and constricting the efferent arteriole $(30,45,50)$. It may cause progressive renal failure in animal models.

If ANP is the final modulator of Na balance, there is a paradox. In advanced cirrhosis, there is an increase in preload and a decrease in central volume and EAV. ANP levels are elevated (50). Likewise in CHF there is a decrease in EAV and an increase in preload and again ANP levels are elevated. Physiologically both situations should invoke $\mathrm{Na}$ retention due to the decrease in the EAV, which in turn should shut off natriuresis, but in both of these situations ANP is elevated.
The arterial natriuretic peptides are primarily vasoactive and act on multiple sites of the nephron including the proximal tubule.

\section{CONCLUSION}

The cumulative data presented in this paper lend support to the view that xanthurenic acid $8-O-\beta$-D-glucoside and xanthurenic acid 8-O-sulfate could be the long sought after and elusive natriuretic hormone. But to validate, or refute this thesis, additional experimental evidence is required. A partial list of key areas of future study includes:

1. A sensitive assay system for quantifying the levels of the putative hormone in body fluids.

2. Establishing the site of production.

3. The character of the signaling process (including the nature of the receptors), involved in initiating and controlling the induced natriuresis.

4. The enzymes involved in the synthesis.

\section{ACKNOWLEDGMENTS}

Thanks to Nancy Price for her untiring patience and expertise.

\section{REFERENCES}

1. de Wardener HE, Mills IH, Clapham WF, Hayter CJ. Studies on the efferent mechanism of the sodium diuresis which follows the administration of intravenous saline in the dog. Clin Sci (1961) 21:249-58.

2. Mills IH, de Wardener HE, Hayter CJ, Clapham WF. Studies on the afferent mechanisms of the sodium diuresis which follows the administration of saline in the dog. Clin Sci (1961) 21:259-64.

3. Nutbourne DM, de Wardener HE. The effect of a water diuresis on the urinary excretion hydrogen ions in man. Clin Sci (1961) 20:63-73.

4. Bricker NS. The control of sodium excretion with normal and reduced nephron populations. The pre-eminence of third factor. Am J Med (1967) 43:313-21. doi:10.1016/0002-9343(67)90188-X

5. Bricker NS, Zea L, Shapiro M, Sanclemente E, Shankel S. Biologic and physical characteristics of the non-peptidic, non-digitalis-like natriuretic hormone. Kidney Int (1993) 44:937-47. doi:10.1038/ki.1993.335

6. Bourgoignie J, Klahr S, Bricker NS. Inhibition of transepithelial sodium transport in the frog skin by a low molecular weight fraction of uremic serum. J Clin Invest (1971) 50:303-11. doi:10.1172/JCI106495

7. Buckalew VM, Martinez FJ, Green WE. The effect of dialysates and ultrafiltrates of plasma of saline-loaded dogs on toad bladder sodium transport. J Clin Invest (1970) 49:926-35. doi:10.1172/JCI106312

8. Fine LG, Bourgoignie JJ, Hwang KH, Bricker NS. On the influence of the natriuretic factor from patients with chronic uremia on the bioelectric properties and sodium transport of the isolated mammalian collecting tubule. J Clin Invest (1976) 58:590-7. doi:10.1172/JCI108505

9. Fine LG, Bourgoignie JJ, Weber H, Bricker NS. Enhanced end-organ responsiveness of the uremickidney to the natriuretic factor. Kidney Int (1976) 10:364-72. doi:10.1038/ki.1976.122

10. Bricker NS, Klahr S, Purkerson M, Schultze RG, Avioli LV, Birge SJ. In vitro assay for a humoral substance present during volume expansion and uraemia. Nature (1968) 219:1059-1059. doi:10.1038/2191058a0

11. Cain CD, Schroeder FC, Shankel SW, Mitchnick M, Schmertzler M, Bricker NS. Identification of xanthurenic acid 8-O- $\beta$-D-glucoside and xanthurenic acid 8 O-sulfate as human natriuretic hormones. Proc Natl Acad Sci U S A (2007) 104:17873-8. doi:10.1073/pnas.0705553104

12. Bourgoignie JJ, Hwang KH, Ipakchi E, Bricker NS. The presence of a natriuretic factor in urine of patients with chronic uremia. The absence of the factor in nephroticuremic patients. J Clin Invest (1974) 53:1559-67. doi:10.1172/ JCI107706

13. Danovitch GM, Bourgoignie JJ, Bricker NS. Reversibility of the "salt-losing" tendency of chronic renal failure. N Engl J Med (1977) 296:14-9. doi:10.1056/ NEJM197701062960104 
14. Epstein M. Renal effects of head-out water immersion in man: implications for an understanding of volume homeostasis. Physiol Rev (1978) 58:529-81.

15. Epstein M, Bricker NS, Bourgoignie JJ. Presence of a natriuretic factor in urine of normal men undergoing water immersion. Kidney Int (1978) 13:152-8. doi:10.1038/ki.1978.22

16. Favre H, Hwang KH, Schmidt RW, Bricker NS, Bourgoignie JJ. An inhibitor of sodium transport in the urine of dogs with normal renal function. J Clin Invest (1975) 56:1302-11. doi:10.1172/JCI108206

17. Hoffman A, Ovcharenko E, Karram T, Okun-Gurevich M, Goltzman I, Cain $\mathrm{C}$, et al. Renal effects of a novel endogenous natriuretic agent xanthurenic acid 8-O- $\beta$-D-glucoside in rats. Physiol Rep (2013) 1:e00155. doi:10.1002/phy2.155

18. Hamlyn JM, Blaustein MP, Bova S, DuCharme DW, Harris DW, Mandel F, et al. Identification and characterization of a ouabain-like compound from human plasma. Proc Natl Acad Sci U S A (1991) 88:6259-62. doi:10.1073/pnas.88.21. 9907-d

19. Dvela M, Rosen H, Ben-Ami HC, Lichtstein D. Endogenous ouabain regulates cell viability. Am J Physiol Cell Physiol (2012) 302:C442-52. doi:10.1152/ajpcell. 00336.2011

20. Tamura M, Lam TT, Inagami T. Specific endogenous $\mathrm{Na}^{+}, \mathrm{K}^{+}$-ATPase inhibitor purified from bovine adrenal. Biochem Biophys Res Commun (1987) 149:468-74. doi:10.1016/0006-291X(87)90391-3

21. Nesher M, Dvela M, Igbokwe U, Rosen H, Lichtstein D. Physiological roles of endogenous ouabain in normal rats. Am J Physiol (2009) 297:H2026-34. doi:10.1152/ajpheart.00734.2009

22. Blaustein MP, Leenen FHH, Chen L, Golovina VA, Hamlyn JM, Pallone $\mathrm{TL}$, et al. How $\mathrm{NaCl}$ raises blood pressure: a new paradigm for the pathogenesis of salt-dependent hypertension. Am J Physiol (2011) 302:H1031-49. doi:10.1152/ajpheart.00899.2011

23. Tamura M, Konishi F, Sakakibara M, Inagami T. Large scale purification of an endogenous $\mathrm{Na}^{+} / \mathrm{K}^{+}$-pump inhibitor from bovine adrenal glands. In: Bamberg E, Schoner W, editors. Sodium Pump: Structure, Mechanism, Hormonal Control and its Role in Disease. New York, NY: Springer (1994). p. 763-6.

24. Haller ST, Kennedy DJ, Shidyak A, Budny GV, Malhotra D, Fedorova OV, et al. Monoclonal antibody against marinobufagenin reverses cardiac fibrosis in rats with chronic renal failure. Am J Hypertens (2012) 25:690-6. doi:10.1038/ajh. 2012.17

25. Nowicki S, Enero MA, de Lores Arnaiz G. Diuretic and natriuretic effect of a brain soluble fraction that inhibits neuronal $\mathrm{Na}^{+}, \mathrm{K}^{+}$-ATPase. Life Sci (1990) 47:1091-8. doi:10.1016/0024-3205(90)90167-P

26. Kramer HJ, Krampitz A, Bäcker A, Meyer-Lehnert H. Ouabain-like factors in human urine: identification of a Na-K-ATPase inhibitor as vanadiumdiascorbate adduct. Clin Exp Hypertens (1998) 20:557-71. doi:10.3109/ 10641969809053234

27. Beltowski J, Wójcicka G. Regulation of renal tubular sodium transport by cardiac natriuretic peptides: two decades of research. Med Sci Monit (2002) 8:RA39-52.

28. Stingo AJ, Clavell AL, Aarhus LL, Burnett JC Jr. Cardiovascular and renal actions of C-type natriuretic peptide. Am J Physiol (1992) 262:H308-12.

29. Bourgoignie JJ, Hwang KH, Espinel C, Klahr S, Bricker NS. A natriuretic factor in the serum of patients with chronic uremia. J Clin Invest (1972) 51:1514-27. doi:10.1172/JCI106948

30. Brenner BM, Ballerman BJ, Gunning ME, Zeidel ML. Diverse biological actions of atrial natriuretic peptide. Physiol Rev (1990) 70:665-99.

31. Puschett JB, Agunanne E, Uddin MH. Emerging role of bufadienolides in cardiovascular and kidney diseases. Am J Kidney Dis (2010) 56:359-70. doi:10.1053/j. ajkd.2010.01.023

32. Lee CYW, Burnett JC. Natriuretic peptides and therapeutic applications. Heart Fail Rev (2007) 12:131-42. doi:10.1007/s10741-007-9016-3

33. Manunta P, Messaggio E, Ballabeni C, Sciarrone MT, Lanzani C, Ferrandi $\mathrm{M}$, et al. Plasma ouabain-like factor during acute and chronic changes in sodium balance in essential hypertension. Hypertension (2001) 38:198-203. doi:10.1161/01.HYP.38.2.198

34. Anderson DE, Fedorova OV, Morrell CH, Longo DL, Kashkin VA, Metzier JD, et al. Endogenous sodium pump inhibitors and age-associated increases in salt sensitivity of blood pressure in normotensives. Am J Physiol (2008) 294:R1248-54. doi:10.1152/ajpregu.00782.2007

35. Katz A, Lifshitz Y, Bab-Dinitz E, Kapri-Pardes E, Goldschleger R, Tal DM, et al. Sensitivity of digitalis glycosides for isoforms of human Na,K-ATPase. J Biol Chem (2010) 285:19582-92. doi:10.1074/jbc.M110.119248
36. Liu J, Xie Z-J. The sodium pump and cardiotonic steroids-induced signal transduction protein kinases and calcium-signaling microdomain in regulation of transporter trafficking. Biochim Biophys Acta (2010) 1802:1237-45. doi:10.1016/j.bbadis.2010.01.013

37. Khundmiri SJ. Advances in understanding the role of cardiac glycosides in control of sodium transport in renal tubules. J Endocrinol (2014) 222(1):R11-24. doi:10.1530/JOE-13-0613

38. Gupta S, Yan Y, Malhotra D, Liu J, Xie Z, Najjar SM, et al. Ouabain and insulin induce sodium pump endocytosis in renal epithelium. Hypertension (2012) 59:665-72. doi:10.1161/HYPERTENSIONAHA.111.176727

39. Periyasamy SM, Liu J, Tanta F, Kabak B, Wakefield B, Malhotra D, et al. Salt loading induces redistribution of the plasmalemmal $\mathrm{Na} / \mathrm{K}$-ATPase in proximal tubule walls. Kidney Int (2005) 67:1868-77. doi:10.1111/j.1523-1755.2005. 00285.x

40. Nechay BR, Chinoy DA. Effect of ouabain on renal transport of P-aminohippuric acid (PAH) and blood flow in the dog. Eur J Pharmacol (1968) 3:322-9. doi:10.1016/0014-2999(68)90115-5

41. Liu J, Yan Y, Liu L, Xie Z, Malhotra D, Joe B, et al. Impairment of Na/K-ATPase signaling in renal proximal tubule contributes to Dahl salt-sensitive hypertension. J Biol Chem (2011) 286:22806-13. doi:10.1074/jbc.M111.246249

42. Zhang J, Lee MY, Cavalli M, Chen L, Berra-Romani R, Balke CW, et al. Sodium pump $\alpha 2$ subunits control myogenic tone and blood pressure in mice. J Physiol (2005) 569:243-56. doi:10.1113/jphysiol.2005.091801

43. Blaustein MP, Zhang J, Chen L, Song H, Raina H, Kinsey SP, et al. The pump, the exchanger, and endogenous ouabain. Signaling mechanisms that link salt retention to hypertension. Hypertension (2008) 53:291-8. doi:10.1161/ HYPERTENSIONAHA.108.119974

44. Fedorova OV, Talan MI, Agalakova NI, Lakatta EG, Bagrov AY. Endogenous ligand of $\alpha_{1}$ sodium pump, marinobufagenin, is a novel mediator of sodium chloride-dependent hypertension. Circulation (2002) 105:1122-7. doi:10.1161/ hc0902.104710

45. Light DB, Corbin JD, Stanton BA. Dual ion channel regulation by cyclic GMP and cyclic-dependent protein kinase. Nature (1990) 344:336-9. doi:10.1038/ $344336 \mathrm{a} 0$

46. Valdivieso A. The kidney in chronic liver disease: circulatory abnormalities, renal sodium handling and role of natriuretic peptides. Biol Res (1998) 31:291-304.

47. Weidmann P, Hasler L, Gnadinger MP, Lang RE, Uehlinger DE, Shaw S, et al. Blood levels and renal effects of atrial natriuretic peptide in normal man. J Clin Invest (1986) 77:734-42. doi:10.1172/JCI112368

48. Pandey KN. Biology of natriuretic peptides and their receptors. Peptides (2005) 26:901-32. doi:10.1016/j.peptides.2005.03.055

49. Eiskjaer H, Pedersen EB. Dose-response study of atrial natriuretic peptide bolus injection in healthy man. Eur J Clin Invest (1993) 23:37-45. doi:10.1111/j.13652362.1993.tb00715.x

50. Gunning ME, Brenner BM. Natriuretic peptides and the kidney: current concepts. Kidney Int (1992) 42:S127-33.

51. Yates NA, McDougall IG. Effect of direct arterial infusion of bufalin and ouabain in conscious sheep. Br J Pharmacol (1993) 108:627-30. doi:10.1111/j.1476-5381. 1993.tb12852.x

Conflict of Interest Statement: During the long period of study covered by this review, major support was provided by Program Project Grants from the NIH and from Naturon Pharmaceutical Company. The authors do not have any conflict of interest in relation to this review.

Received: 02 October 2014; accepted: 24 November 2014; published online: 11 December 2014.

Citation: Bricker NS, Cain CD and Shankel S (2014) Natriuretic hormone: the ultimate determinant of the preservation of external sodium balance. Front. Endocrinol. 5:212. doi: $10.3389 /$ fendo.2014.00212

This article was submitted to Neuroendocrine Science, a section of the journal Frontiers in Endocrinology.

Copyright (c) 2014 Bricker, Cain and Shankel. This is an open-access article distributed under the terms of the Creative Commons Attribution License (CC BY). The use, distribution or reproduction in other forums is permitted, provided the original author(s) or licensor are credited and that the original publication in this journal is cited, in accordance with accepted academic practice. No use, distribution or reproduction is permitted which does not comply with these terms. 